\title{
Why White, Not Keynes? \\ Inventing the Postwar International \\ Monetary System
}

James M. Boughton 


\title{
IMF Working Paper
}

Policy Development and Review Department

Why White, Not Keynes?

Inventing the Postwar International Monetary System

Prepared by James M. Boughton ${ }^{1}$

March 2002

\begin{abstract}
The views expressed in this Working Paper are those of the author $(\mathrm{s})$ and do not necessarily represent those of the IMF or IMF policy. Working Papers describe research in progress by the author(s) and are published to elicit comments and to further debate.
\end{abstract}

The international monetary system is largely the product of negotiations during World War II between U.S. and U.K. officials, led respectively by Harry Dexter White and John Maynard Keynes. The design of the system, especially the International Monetary Fund, reflects the U.S. plan much more than the British. That outcome resulted not only from the superior economic position of the United States but also from differences between White's and Keynes's views on key issues. Examination of White's economic papers shows that he was more multilateral than Keynes and placed a higher priority on monetary discipline.

JEL Classification Numbers: B22, B31, F33, F41

Keywords: IMF, Harry Dexter White, Keynes, open economy models

Author’s E-Mail Address:jboughton@imf.org

\footnotetext{
${ }^{1}$ The bulk of this paper was written while I was at St. Antony's College, University of Oxford, on leave from the IMF. A previous draft was presented at a conference in Beersheba, Israel, in June 2001. The paper is to be published in The Open Economy Macromodel: Past, Present, and Future, edited by Arie Arnon and Warren Young (Kluwer Publishing). I am grateful to Don Moggridge, Jacques Polak, Roger Sandilands, and conference participants for comments on that draft. The views expressed herein are personal and should not be attributed to any institution.
} 
I. Why White?

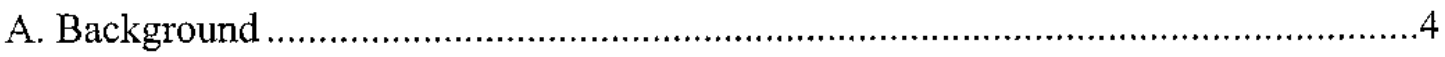

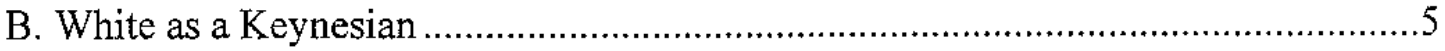

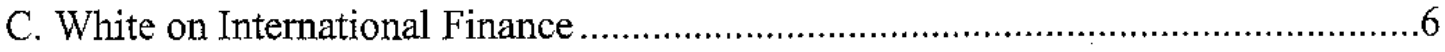

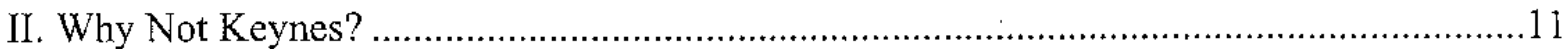

A. Keynes as Defender of the Empire …………….............................................12

B. The Secondary Role of Inflation Prevention..........................................................16

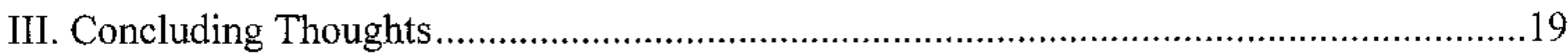

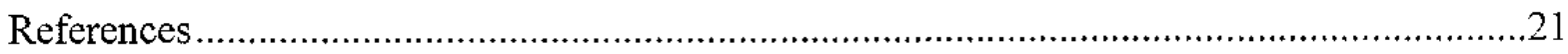

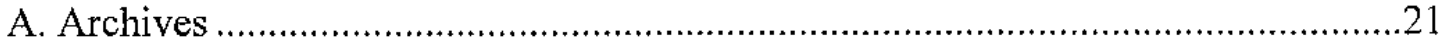

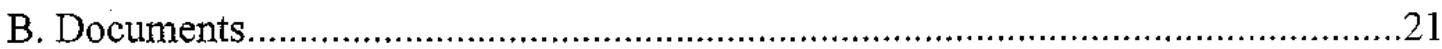

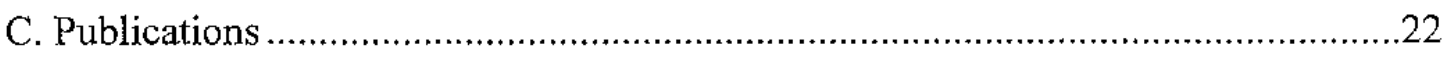

Table 1. IMF Quotas, Access, and World Trade ……....................................................... 
In Britain [Harry White] is too often thought of as some dim scribe, some kind of robot, who wrote ... an inferior version of the Keynes plan - mainly to vex the British! Far different was the real man. He was a remarkable figure, who should be accorded an honourable place in British annals.

$$
\text { Harrod (1951), pp. 537-38 }
$$

Harry White's role in the British loan negotiations is, like almost everything else in his career, mystifying.

$$
\text { Skidelsky (2000), p. } 424
$$

The design of the IMF and its role in today's international monetary system are largely the product of wartime negotiations between the United States and the United Kingdom in the run-up to the Bretton Woods conference of 1944. The two lead negotiators, John Maynard Keynes for the British and Harry Dexter White for the Americans, each developed an independent plan for a multilateral institution that would promote stable finance and growing international trade and would help prevent a recurrence of the disastrous mistakes made after the first World War. Where the two plans differed, the final outcome was dominated by the White Plan, not that of Keynes.

Leaving aside the technical and structural issues, three differences in the two plans were particularly significant. First, White's IMF was to be smaller than Keynes's and would allocate its scarce resources selectively rather than making them freely available to members on demand. Second, White's IMF would lend national currencies rather than a newly created international asset (Keynes's "bancor"). Third, White's IMF would be a more multilateral institution, rather than one designed and dominated by two "founder-States," as envisaged by Keynes. Both the process and the outcome at Bretton Woods represented compromises between these two initial visions, but the British gave up far more than the Americans. Why was Keynes so unsuccessful?

In Washington Lord Halifax

Once whispered to Lord Keynes:

"It's true they have the money bags

But we have all the brains."

The conventional wisdom about Bretton Woods is that the British, led by the greatest economist of the twentieth century, had the right ideas about how to design the institutions that would shape the international monetary system after the war. The Americans, however, had the economic power, and they used that power to control the outcome. Like all oversimplifications, this one has a certain credibility, but it is far from conveying the full story.

${ }^{2}$ Gardner (1980), p. xiii; cited as "found on a yellowing piece of paper salvaged from the first Anglo-American discussions ... about postwar economic arrangements." Gardner found the note among White's personal papers at Princeton; its authorship was not indicated, but Dennis Robertson seems the most likely candidate. 
Both the Keynes Plan and the White Plan contained much of value, and both contained flaws. The final product - the Articles of Agreement for the IMF drafted at Bretton Woodswas an improvement over both plans, but it too contained flaws. White, of course, was working to promote U.S. economic and political interests, just as Keynes was focused on British interests. That White's conception of the postwar system essentially prevailed is attributable only in part to the superior economic strength of the United States. Also important was the fact that White understood that American ascendancy depended on a multilateral and multinational regime of open trade and finance. British aspirations, in contrast, depended on perpetuation of the system of Empire preferences and - despite American opposition to that systemdevelopment of a bilateral economic partnership with the United States. The hopelessness and inconsistency of that position doomed the Keynes Plan from the outset.

This paper begins by sketching the importance of Harry Dexter White as a U.S. government economist and explaining the background to his work on the international monetary system. It then looks at the similarities in and contrasts between White's and Keynes's conceptions and draws a few lessons for our understanding of today's system.

\section{WHY WhITE?}

In stark and utter contrast to Keynes, White may be the least understood major economist in history. For the most part, his legacy is in institutional practice rather than publications. Throughout much of his career, his ideas were filtered through bureaucracy and diplomacy and were seldom subjected to academic peer review. To uncover his thoughts and contributions requires sifting through masses of internal government memorandums. Those documents cover a wide variety of economic policy issues, but almost all were written in response to crises during the depression and war years of the $1930 \mathrm{~s}$ and early $1940 \mathrm{~s}$.

\section{A. Background}

Harry White was a second-generation American, born in Boston in 1892 to immigrants from Lithuania. Aside from one term at the Massachusetts Agricultural College in Amherst, he began his university education only at the age of 29 , after stints in his father's hardware store and in the U.S. army during World War I. He studied at Columbia, then at Stanford where he completed bachelor's and master's degrees in economics, and finally at Harvard, where he completed a Ph.D. under Frank Taussig. His dissertation, on the French international accounts, won the David A. Wells prize and was published by Harvard University Press in 1933 . Now 40 years old, White taught briefly at Harvard and then took up a position teaching at Lawrence College in Wisconsin. In June 1934, he accepted an invitation from Jacob Viner to spend the summer at the U.S. Treasury in Washington on a special survey of monetary and banking practices. That led to a permanent job that culminated in White being placed in charge of all international analysis in 1941, officially becoming Assistant Secretary (effectively the chief economist in the Treasury) in 1945, and finally becoming the first U.S. Executive Director in 
the International Monetary Fund (effectively the number two official in the institution). ${ }^{3}$ His health then deteriorated, and he died of a heart attack in 1948.

White's published work, other than his dissertation, is limited to brief bursts. As a graduate student, he contributed to the third edition of Taussig's empirical work on tariffs by evaluating the ability of several U.S. industries to compete in world markets without tariff protection (Taussig, 1931, Part V). While in Wisconsin in 1933, he wrote a review article for the Quarterly Journal of Economics at Taussig's request, on Gottfried Haberler's Der Internationale Handel and Bertil Ohlin's Interregional and International Trade (White, 1934). He then was otherwise occupied until 1943, when he presented a paper on postwar financial arrangements at the annual meetings of the American Economic Association (White, 1943). After the Bretton Woods conference, he wrote at least two articles on the IMF (White, 1945, 1947). Those last three papers, however, were expositions of the case for creating the IMF and the World Bank, not analytical work. None of White's published articles reveals his views on international monetary policy in any depth. For that, one needs to turn to the extensive collection of his Treasury writings in the archival collections at Princeton University and the U.S. National Archives, especially for the period 1934-38, when White was an economic analyst and not yet a bureaucrat with a subordinate staff to draft papers for him. ${ }^{4}$

Given the inaccessibility of White's work, it is not surprising that his role has been largely neglected except as an architect of the IMF. Two aspects of this neglect warrant examination: White as an early Keynesian, and as an international monetary economist.

\section{B. White as a Keynesian}

Most surveys of the development of counter-cyclical fiscal policy in the United States have either totally ignored White (Laidler, 1999) or have mentioned him en passant as having been an influential New Dealer who was in turn influenced by Keynes. Roy Harrod (1951) noted that White "had very solid intellectual quality and was an ardent admirer of Keynes" economic work" (p. 538). Robert Lekachman (1967) also noted Keynes's influence on White, on both fiscal and exchange rate policies (pp. 105-7). Herbert Stein (1969) included White in a list of U.S. government economists who supported the use of counter-cyclical fiscal policy to combat the recession of 1937-38 (p. 102).

The major exception to this minimization has been June Flanders (1990), who recognized White's importance as a contributor to economic thought. Based on a textual exegesis of his Ph.D. dissertation (pp. 236-41), she concluded that he was a "late classical"

${ }^{3}$ For more detailed biographies, see Rees (1973) and Craig (1999).

${ }^{4}$ White was named Director of the Division of Monetary Research at the U.S. Treasury in March 1938. A majority of memorandums after that date were drafted initially by economists in the Division. 
economist (along with his teachers, Taussig and Viner) who "comes closer to keynesian macro analysis than any of the others in the group" (p. 240). She noted in particular that White's analysis of the effects of an exogenous real shock on trade flows prefigured the "income" or absorption approach in contrast to the prevailing acceptance of the price elasticities approach.

A recent paper by David Laidler and Roger Sandilands (2002) has resurrected a 1932 memorandum co-authored by Lauchlin Currie, P. T. Ellsworth, and White, which clearly sets out a scheme for combating the depression through vigorously expansionary monetary and fiscal policies. Laidler and Sandilands argue that this memorandum illustrates the intellectual origins at Harvard of thinking on counter-cyclical macroeconomic policy, and that the implicit model was more monetary than "Keynesian" (i.e., the memorandum suggested that fiscal expansion would stimulate the economy via its effect on the supply of money). Although it is impossible to determine the separate contributions of the individual authors, the memo definitively overthrows the notion that White's views on fiscal policy merely reflected those of Keynes.

\section{White on International Finance}

White's views on international monetary economics also appear to have developed independently of Keynes and to have been influenced particularly by another of his Harvard teachers, Allyn Young. Unfortunately, White's thinking on these issues evolved erratically, and his writings do not reveal a fully consistent position. His fundamental vicw was that monetary and exchange rate policy should be subjected to rules, but he occasionally suggested that those rules should be applied with enough flexibility to enable central banks to opt out when necessary to respond to extreme circumstances. ${ }^{5} \mathrm{He}$ first articulated this "fixed but adjustable" view, which prefigured the recent development of state-contingent monetary policy rules (Flood and Isard, 1989), in his 1934 Treasury report on the role of gold. Viner had requested the report in the wake of the January 1934 pegging of the dollar at the devalued rate of $\$ 35$ an ounce. In a 400-page report completed in three months, White concluded that adherence to the gold standard was a useful disciplinary device for monetary policy as long as the central bank was prepared to change the exchange rate in "pcriods of stress" ("Selection of a Monetary Standard ...," 1934, p. 232).

Keynes articulated a similar proposal for state-contingent policy rules the following year, in an article published in Lloyd's Bank Monthly Review. IJe argued that central banks should try to agree on levels for exchange rates and thereby for parities against gold that would

\footnotetext{
${ }^{5}$ For an overview on the history of the debate on rules vs. discretion in monetary policy up to 1930, see Laidler (2001). That debate split fairly cleanly between those favoring rules (including Alfred Marshall and Irving Fisher, who formulated alternative rules to the gold standard) and those favoring discretionary monetary standards (including Knut Wicksell, Ralph Hawtrey, and Allyn Young, whose thinking clearly influenced Keynes and White). Keynes's and White's attempts to articulate state-contingent rules were innovative.
} 
equilibrate the balance of payments; that they should maintain those parities within a limited range through intervention in spot and forward markets; and that they should be mindful of the need to abandon the parities in extremis. "Rigidly fixed parities" would be eschewed in favor of central bank collaboration, subject to an "ultimate individual discretion" for each collaborator to devalue the currency "to relieve either a sudden and severe or a gradual and continuing strain." In contrast to White, however, Keynes explicitly ruled out the use of monetary policy as a first line of defense to relieve such a strain. The rate of interest, in his scheme, was assigned to the goal of full employment: to internal rather than external balance (Keynes, Collected Writings $X X I$, pp. 360-69).

After White's temporary assignment segued into permanent employment at the Treasury, he developed his argument further. A managed currency, without gold or another effective anchor, was a dangerous idea, he argued in January 1935 ("Managed Currency and the Gold Standard"), because it could encourage countries to use the exchange rate to gain a trade advantage. This danger was precisely what many experts in other countries feared had been Roosevelt's intention in driving up the price of gold in the latter months of 1933. Although White did not explicitly criticize the earlier policy, he firmly endorsed the return to gold in 1934. More importantly, he was already suggesting the need for international rules or agreements on when adjustments in exchange rates were appropriate and on how they should be adjusted. ${ }^{7}$ His views, however, were still unsettled, for a few months later he argued in a lengthy memorandum ("Recovery Program ...," 1935) that recovery from the depression would require the active use of exchange rate policy, because - though White did not use this terminologyexchange markets could not be relied upon to restore purchasing power parity following large country-specific real shocks.

White's views on the policy role of the exchange rate developed more clearly in the course of 1935. In an August memorandum, he argued against most measures to stimulate exports, on the grounds that they were neither necessary nor sufficient for a resumption of economic growth and anyway were unlikely to work. Only two proposals for stimulating exports had any merit: an international agreement to stabilize exchange rates and an expansion of official loans to foreign governments ("Why and how exports should be increased," 1935). He worried, however, about the "potential absence of national autonomy in the determination of monetary policy" that would be a by-product of an international monetary agreement

${ }^{6}$ Keynes sketched the essence of this scheme in 1933, in the series of newspaper articles that he published as The Means to Prosperity. There he wryly noted the oddity of the coiner of "barbarous relic" becoming an advocate of "a qualified return to the gold standard" and defended his shift by stressing the opt-out qualifications. See Keynes, Collected Writings $I X$, p. 362 .

${ }^{7}$ For an antecedent and possible influence on White's views, see Young (1929), pp. 370-71. Young, however, was advocating central bank cooperation on intervention policy, not explicitly on exchange rate adjustment. Currie later expressed views similar to White's; see Currie (1936). 
("Monetary Policy," 1935, p. 15). A few months later, therefore, he noted the importance of creating a dollar zone to compete against the sterling area and weaken the influence of sterling as a constraint on U.S. policy. Currency stability, not the relative size of the foreign exchange market, was to be the cornerstone of his strategy for developing the international role of the dollar:

Though it doesn't matter very much whether New York or London does the most foreign acceptance business, it is important to have as many currencies as possible linked to the dollar rather than to sterling, if the rate between dollars and sterling is not fixed. The more currencies tied to the dollar (i.e., exchange rates fixed to dollar), the less power will British authorities have to influence American monetary policy. The more international business a country does, the more likely will it be to attract other currencies in its orbit of influence, and the more currencies it attracts the greater will be its international business ("The United Kingdom ...," 1935, p. 24).

White's experience with the weakness of the U.S. economy in the 1930 s made him curiously insecure about the future role of the dollar in the international economy. He failed to anticipate that the dollar would become the premier currency in the postwar world and that it would soon constitute the bulk of international reserve assets held by central banks all over the world. That role, he believed, would continue to be played by gold. In 1940, he began work on a lengthy manuscript on "The Future of Gold," which he seems to have intended to be the culmination of his thinking on exchange rate policy. He worked on it sporadically for at least four years, but he never brought it to a publishable stage, and much of it remained unrevised from 1940.

"The Future of Gold" argued that the only way any country could induce investors to hold liquid claims on it for extended periods was to create complete confidence that its currency would not be devalued in the foreseeable future. Since no major country would be willing to surrender its sovereignty over the valuation of its currency, the ability to create such confidence was limited. Investors therefore had and would continue to have a preference for gold over currencies or other liquid assets, though they could be induced to hold redeemable currencies if the risk of devaluation was not too great. "Many decades at least will have to pass before many countries will elect to keep their reserves in the form of some foreign paper currency never redeemable in gold rather than in the form of gold or currency redeemable in gold" (Section IV, p. 6). Moreover, he rejected on time-inconsistency grounds the idea that countries could credibly effect a co-operative agreement to fix exchange rates without an anchor to gold. Confronted with the possibility of devaluing (or imposing exchange restrictions) as the "lesser evil," rather than contracting the economy, "the sovereign power will usually elect to pursue the lesser evil" (Section IV, p. 4).

Despite White's occasional skepticism about the viability of international currency agreements, he generally favored multilateral co-operation. Here his natural instincts were reinforced by his practical experience in trying to manage the exchange rate between the dollar and the pound sterling. In the spring of 1935, White made his inaugural overseas trip for the 
Treasury, where he first met Keynes and other British officials. He seems to have made a bad impression on many of them (Drummond, 1981, p. 192), and he may have been overly encouraged by Keynes's apparent desire for a "de facto stabilization" of sterling against the dollar and thereby against gold (see "Personal Report ...," 1935, and "Summary of Conversations," 1935). A year later, during the negotiations that would lead to the Tripartite Agreement among the United States, the United Kingdom, and France, White's considered opinion was that the exchange rate between the dollar and the pound (then hovering around its historic parity of \$4.86) was appropriate, while the French franc had to be devalued. $\mathrm{He}$ worried, however, that the British might not agree and would retaliate against a franc devaluation by depreciating sterling against the dollar ("French Devaluation," 1936). U.K. Treasury officials reacted bitterly but helplessly to the U.S. position, arguing that at $\$ 4.86$ the pound was overvalued (while acknowledging that it was undervalued relative to the franc).

The difficulty was not that opinions differed on the desirability of stabilizing rates; it was that they differed on the equilibrium level. The Tripartite Agreement, weak though it was in its mechanisms for further collaboration and enforcement, helped temporarily to resolve the Anglo-American dispute by limiting the size of the French devaluation and thereby the size of the effective revaluation of the pound. More importantly, it reinforced in White's mind the benefits of multilateral agreements over bilateral negotiations with the British.

Another issue on which White developed his views early and independently from Keynes, and which came to have great importance later on, was the control of international capital flows. White's Ph.D. dissertation demonstrated that the balance of the effects of capital exports on the pre-war French economy was not unambiguously positive. Given the possibility of harm from unbridled flows, White concluded that "some measure of the intelligent control of the volume and direction of foreign investments is desirable" (White, 1933, pp. 311-12).

"Intelligent control" implied channeling rather than stopping such flows, and it was a weapon that White thought should be held in reserve and not applied indiscriminately. His 1934 report to Viner argued that capital controls were normally unnecessary, but that legislation should be in place that would enable the Federal Reserve to impose and enforce controls quickly when they werc needed to prevent a speculative flight of capital. He was fully aware of the "many channels of evasion" that made complete control impossible, but he argued that the magnitude of capital flight could be reduced enough to protect the country's reserve position ("Selection of a Monetary Standard," 1934, Chapter 17). Similarly, he initially expressed doubts about the necessity of controlling the massive gold inflows to the United States, even though such flows were potentially costly ("Gold Imports into the United States," 1935).

White's enthusiasm for capital controls perked up in the second half of the 1930s. As capital continued to flow into the country in 1936, he proposed an elaborate scheme to impose 100 percent reserve requirements on forcign-owned bank deposits, coupled with a stamp tax on securities transfers to foreigners to limit evasion ("Increase in Reserves ...," 1936). But his clearest statement of the rationale for controls came in 1938, in response to the ongoing depreciation of the French franc, which White argued had not helped the French economy. Of the three options under consideration for policies to strengthen the French balance of 
payments - further depreciation, import controls, or capital controls- White argued that "the imposition of exchange controls over non-commercial transactions ... seems to us now, as it has in the past, to be the best of the bad choices" ("What should our answer be ...," 1938). This second-best reasoning eventually was carried over into White's 1942 blueprint for a Stabilization Fund. Although the elimination of foreign exchange restrictions was a primary purpose of the Fund, the plan acknowledged that "there are situations in which many countries frequently find themselves, and which all countries occasionally meet, that make inevitable the adoption of controls" (Horsefield, 1969, p. 63).

In this domain, what was second best to White was second nature to Keynes. In contrast to White's acceptance of controls as occasionally to be tolerated, Keynes regarded them as essential for stable international finance. ${ }^{8}$ His 1942 plan for an International Clearing Union cited the facilitation of capital controls as one advantage of the proposal, since it would encourage international co-operation on controls, "which we have now gone a long way towards perfecting" in Britain. To that end, it would be "vital" to distinguish "floating funds" and "speculative movements or flights" from "genuine new investment" and flows that "help to maintain equilibrium" (Horsefield, 1969, p. 13).

Before leaving the subject of White's views on controls, it is necessary to clear up a persistent misunderstanding about his opinion of the Soviet economic system. The only textual support for Robert Skidelsky's recent assertion that White "greatly admired Soviet planning" (Skidelsky, 2000, p. 242) is a 1933 letter to Taussig, in which White reported that he was studying Russian "in the hope that I may get a fellowship which would enable me to spend a year chiefly in Russia. There I should like to study intensively the technique of planning at the Institute of Economic Investigation of Gosplan" (quoted in Rees, 1973, p. 39). The context of this proposal, explained in the same letter, was White's concern about a growing movement in the United States for protectionism and for "virtual economic self-sufficiency." How, he wondered, could the United States protect itself from external shocks "without sacrificing either stabilizing influences of int. econ. relations or the gains from for. trade. The path, I suspect, may lie in the direction of centralized control over foreign exchanges and trade. I have been ... reading and thinking about the problem but my opinion is as yet unsettled" (emphasis added). Before long, as the discussion above has shown, his opinion settled on a combination of monetary stability and capital controls as the solution to this problem. The Gosplan never again figured as an influence, although White was tireless in his opposition to protectionism throughout the 1930s. ${ }^{9}$

\footnotetext{
${ }^{8}$ Currie also regarded capital controls as necessary "to reduce the magnitude of capital movements and to prevent the adjustment of trade to such movements" (Currie, 1936, quoted in Sandilands, 1990, p. 55). Currie's view thus was closer to Keynes than to White.

${ }^{9}$ In 1938, for example, White prepared Secretary Morgenthau's response to suggestions for a "Buy American" scheme. That proposal, he argued, would be "quite inadvisable because U.S. policy should be to promote, not discourage, international trade. A 'Buy American' program
} 
Like President Franklin D. Roosevelt and Treasury Secretary Henry Morgenthau, Jr., White did not believe that the Soviet Union was interested in territorial expansion. It followed that Nazi Germany was a more direct threat to the United States and its allies. In one of his last writings, he admitted that neither he nor "any responsible official of the member governments" [of the IMF] had foreseen in 1944 the post-war political split and tensions between the United States and the Soviet Union" ("rough draft of a statement ...," 1948, p. 4). He was, however, cognizant of the dangers posed by Russia's totalitarianism and its "ideological aggression," which made poor countries particularly susceptible to the appeal of international communism. This concern was doubtless a motivation for his longstanding interest in U.S. economic and financial support for Latin America, which dated from the mid-1930s and continued right up to the time of his death in $1948 .^{10}$

\section{Why Not KeYNES?}

On most major issues of economic policy, Keynes and White held similar views. On domestic macroeconomic policy, of course, both were "Keynesian" in the most common sense of that term: they favored the active use of counter-cyclical policies to maintain high levels of employment. Internationally, both men favored fixed but adjustable exchange rates in support of open trade in goods and services, protected by a degree of control over capital flows. But they also differed importantly on specific issues, especially in the framework for postwar planning. On balance, White tended to be more realistic, partly because Keynes was forced to fight a rearguard battle to prevent Britain from losing too much control over its finances and partly because White placed greater stress on price stability and monetary discipline as a policy goal.

The two men collaborated closely in the final stages of designing the IMF, but their initial plans were independent. White began sketching a framework in 1941 and produced an initial draft in January 1942. He did not see Keynes's plan for an International Clearing Union until August. Nonetheless, he may have been influenced by Keynes's thinking on international monetary reform. A number of elements in the design of the IMF first appeared in a series of newspaper articles by Keynes that was published in pamphlet form in the United States in 1933. The question once posed by Skidelsky, "Did Harry Dexter White read the American edition of The Means to Prosperity?" (Skidelsky, 1992, p. 472), is unanswerable, but it would be reasonable to suppose that he did. Second, Keynes spent three months in Washington in mid1941, during which time he held extensive discussions with U.S. Treasury officials, including

fosters the development of the kind of unintelligent and extreme nationalism which is doing so much to threaten world peace" ("General Hines' suggestion ...," 1938). The memorandum also opposed stamping U.S.-made goods as "Made in America," on the grounds that the practice might discourage imports.

${ }^{10}$ Before the creation of the Grand Alliance against the Axis in 1942, White regarded both Germany and the Soviet Union as equally dangerous totalitarian states. See "The Future of Gold," Section IV, pp. 15-16; and the untitled document beginning "Should Germany succeed ...," 1940. 
White, on bilateral financial assistance for the British war effort. If either man was already thinking about postwar monetary planning, he might well have raised the issue informally with the other, though no documentation supports such a conjecture. ${ }^{11}$ Nonetheless, whatever crossfertilization might have occurred, it is clear that they maintained different positions on some issues both before and after they began intensive discussions. ${ }^{12}$

\section{A. Keynes as Defender of the Empire}

As Robert Skidelsky stresses throughout the final volume of his biography, Keynes spent much of his energies during the war "fighting for Britain," not against the Axis but against the ascending economic power of the United States. The United Kingdom needed substantial financial support from the United States not only to fight the war but also to rebuild its economy after the war. British officials also wanted to perpetuate the system of Empire preferences within a trading zone that excluded the United States, and they wanted to have as much time as possible to unblock the more than $\$ 13$ billion in sterling balances that countries had accumulated in London during the war. Both of those objectives clashed with U.S. economic interests and were strongly opposed by the Roosevelt administration. Keynes was forced to negotiate with the U.S. Treasury to gain its financial support while conceding as little as he could on trade and currency restrictions. ${ }^{13}$

White knew the strength of his hand, and he did not shrink from playing it to maximum advantage. He had no desire to harm or weaken the U.K. economy, but he (and other U.S. officials) interpreted its circumstances and interests differently from Keynes (and other British officials). In White's view, Britain would benefit as much as any country from "fair trade and

${ }^{11}$ Keynes's 1941 trip to Washington is described in Harrod (1951), pp. 505-14, Moggridge (1992), pp. 655-62, and Skidelsky (2000), pp. 107-31. None of these accounts includes any record of the substance of Keynes's discussions with White.

12 Following the 1935 and 1941 meetings mentioned above, Keynes and White met several times to negotiate a compromise agreement for the postwar financial institutions: in London in October 1942, in Washington in September-October 1943, and in various U.S. locations (Atlantic City, New Jersey; Bretton Woods, New Hampshire; and Washington) from June to October, 1944. They met again in Washington from September to December 1945, where they engaged in brutally lengthy negotiations on postwar financial assistance to Britain. Their final encounter was at the inaugural meeting of governors of the IMF and the World Bank in Savannah, Georgia, in March 1946.

${ }^{13}$ Keynes's personal views on trade and currency liberalization were, broadly speaking, more liberal than the official British position, but he clearly regarded full liberalization as a long-lerm goal. See Moggridge (1991), pp. 805-09, for an account of Keynes's efforts to persuade the British Treasury to let him take a more realistic position in his negotiations with the U.S. Treasury on postwar financial assistance. 
currency practices. ... With expanded world trade, British exporters will find better markets. But it will take several years ..." ("Anglo-American financial Agreement," 1946, p. 6). He made three specific objections to British arguments.

First, White did not accept British projections of their postwar financial needs, and therefore he was reluctant to push within the administration for large-scale assistance. He readily acknowledged Britain's need for credits, but not of the magnitude that was being requested and not on such generous terms. Moreover, as he told Morgenthau, the United Kingdom "could absorb endless billions of dollars, and any vague commitment to England's future prosperity would threaten both the financial and political position of the United States in the postwar world." 14 White's overly optimistic view about British prospects for economic recovery conditioned not only the terms of bilateral assistance but also the scale of the multilateral financial institutions that were to be created. Indeed, White saw the IMF and the World Bank as a multilateral and far more effective alternative to bilateral financial assistance to Britain. His 1945 article for Foreign Affairs argued that a large-scale bilateral loan would "completely miss the real postwar problem" (p. 207):

To facilitate the restoration of balance in her international accounts Britain needs an expansion of world trade. A loan to Britain ... will not of itself help significantly with Britain's problem, or with the world's problem of establishing a sound postwar pattern of international payments. Such a loan might burden Britain with dollar debt while making no real contribution toward balancing Britain's international payments. On the other hand, the Fund and the Bank, by providing the favorable conditions necessary for expanding world trade and investment, would be of real help ..." (Ibid.).

Second, while White supported Britain's need for a gradual unblocking of sterling balances, he was adamant that this task should be concluded without undue delay. As he wrote in his 1942 plan for the IMF (Horsefield, 1969, p. 47):

Balances owned by residents of another country which have been blocked because holdings of gold and other liquid foreign exchange assets are inadequate $\ldots$ will constitute after the war one of the danger spots to monetary stability, and to resumption of liberal trade policies. If the Fund can eliminate that danger spot it will have justified its existence-even were it to accomplish little else.

Third, and most fundamental, White did not accept the legitimacy of Empire trade preferences, nor of the currency restrictions that supported them. He was sitting on an enormous stockpile of gold that had been accumulating ever since Roosevelt had fixed the price of gold at

${ }^{14}$ The quotation is a paraphrase based on the Morgenthau diaries, in Blum (1967), p. 316. Charles Kindleberger, in his autobiography, recalls participating in wartime discussions in which "White was determined to make the British turn their pockets inside out" (Kindleberger, 1991, p. 66). 
$\$ 35$ an ounce in 1934 , and he was determined to reduce it through a rapid build-up in international trade as soon as the war was over. Neither Congress nor the U.S. business sector would ever accept a policy of encouraging imports unless it was matched by an opening up of world markets to U.S. exports. The major obstacle was the way Britain was running its financial Empire. Keynes was determined to preserve that system, but White was just as determined to build a more open, multilateral system.

Keynes had no chance of ever winning all of these battles. Had he been authorized to sacrifice either U.S. bilateral aid or British trade preferences, he might have been able to make substantial gains on the other. By trying to win on both fronts, he had too little to offer on either. This is not to suggest that Keynes was unwilling to negotiate. Both on postwar bilateral assistance and on the design of the IMF, he showed a great deal of flexibility and a willingness to challenge the positions of his own government. But he had too few opportunities to win the major battles. ${ }^{15}$

The effect of these different views and positions on the international monetary system was that White was more radical and far-reaching than Keynes in the effort to establish multilateralism and currency convertibility. Keynes's resistance to multilateralism was grounded in the need to preserve Britain's special status through its central role in the Empire and its bilateral relationship with the United States. He envisaged the Clearing Union primarily as an agreement between the two "founder-States," with other countries joining it as they wished by complying with specified conditions (see paragraph 17(1) of the 1942 Keynes plan; Horsefield, 1969, p. 6). "Russia, which might be a third founder, if she can be a party to so capitalist-looking an institution, would need special consideration" (paragraph 55; Ibid., p. 15), he wrote in paying lip service to the Soviet Union's importance in the Grand Alliance. But even Russia played no significant part in his thinking, and the paragraph continued: "This [founderState] approach would have the great advantage that the United States and the United Kingdom ... could settle the charter and the main details of the new body without being subjected to the delays and confused counsels of an international conference." ${ }^{16}$ Moreover, he wanted the two founder-States to be completely in charge of running the organization: "The management and the effective voting power might inhere permanently in the founder-States." And he was even nostalgic enough to imagine that the headquarters would be situated in London (Ibid.). ${ }^{17}$

${ }^{15}$ On the British negotiating strategy and tactics and Keynes's role therein, see Pressnell (1986). I am grateful to Don Moggridge for drawing this point to my attention.

${ }^{16}$ Privately, he derisively imagined these "confused counsels" as like a "most monstrous monkey house." Letter to Sir David Walley (30 May 1944), in Keynes, Collected Writings $X X V I$, p. 42.

${ }^{17}$ Keynes dropped the bilateral founder-state idea in subsequent drafts of his plan. On this and other issues, Keynes's early drafts are doubtless a clearer reflection of his personal thinking 
In contrast, White "hoped that some time soon, representatives of various interested governments will meet in conference to explore the possibility of an international stabilization fund and bank" (1942 White Plan; Horsefield, 1969, p. 39). In part, his desire for a multinational conference may have been intended to limit the effect of Keynes's intimidating presence. Canadian, French, and Indian delegations would be particularly useful buffer zones and distractions. More deeply, though, White wanted to ensure the active participation of the Latin American republics and-most of all —of the Soviet Union. For Keynes, Soviet involvement was almost immaterial, because Russia had little effect on U.K. economic interests and would matter little for the success of the international financial institutions. For the United States, and for White, the Soviet Union was by far the most important partner country: not in trade or financial terms, but in terms of its strategic dominance in determining postwar peace and prosperity. ${ }^{18}$ Russian involvement in designing the IMF would clearly promote U.S. policy goals as they were perceived in $1944 .^{19}$

Although a principal goal of White's planning for the postwar system was to re-establish currency convertibility, he recognized that this goal would take years to accomplish. His Stabilization Fund, therefore, was designed for a world dominated by bilateral payments arrangements. A member country could borrow a specified currency from the Fund only "to meet adverse balance of payments to the country whose currency is being demanded" (Horsefield, 1969, p. 41; emphasis added). The evolution of the U.S. dollar and other reserve currencies as vehicles for multilateral settlements was not yet in the picture.

than the ones he circulated later in order to reach a compromise with White. The 1942 draft was the last one that was free of that interaction.

${ }^{18}$ White began advocating substantial financial assistance for the Soviet Union in March 1939. With Neville Chamberlain's government still wavering in its responses to Hitler's acts of aggression, White wrote to Morgenthau that it was time to "clear the decks for future economic collaboration between the two most powerful countries in the world, which, irrespective of their political differences, constitute, for the present at least, the core of resistance against the aggressor nations" (untitled memorandum, "In our opinion ...," 1939, p. 2). Apart from the subsequent period of the Nazi-Soviet pact, treatment of the Soviet Union as an indispensable strategic partner was a mainstay of U.S. policy throughout the war.

${ }^{19}$ Once the Grand Alliance collapsed and the Cold War ensued, White's advocacy of and participation in bilateral cooperation with the Soviet Union was misinterpreted by some as a betrayal of U.S. interests; see Boughton (2001a) and Boughton and Sandilands (2002). Similarly, Skidelsky's assertion that "White's Stabilisation Fund was just one fragment of a much larger design at whose centre lay American-Soviet condominium, not Anglo-American co-operation" (Skidelsky, 2000, p. 243) is without textual foundation. Cooperation was White's stated goal in both cases. 


\section{B. The Secondary Role of Inflation Prevention}

With regard to price movements, Keynes's primary preoccupation throughout the $1930 \mathrm{~s}$ and 1940s was the avoidance of deflationary pressures. This bias carried over to his thinking about the international monetary system (1942 Keynes plan, ๆ 12; Horsefield, 1969, p. 27):

Just as the development of national banking systems served to offset a deflationary pressure which would have prevented otherwise the development of modern industry, so by extending the same principle into the international field we may hope to offset the contractionist pressure which might otherwise overwhelm in social disorder and disappointment the good hopes of our modern world.

In keeping with this goal, Keynes wanted his International Clearing Union to be an international lender of last resort. Countries should know in advance that the institution's resources would be available to them when needed, as long as they were willing to pay an appropriate interest rate. "Our view has been very strongly that if countries are to be given sufficient confidence they must be able to rely in all normal circumstances on drawing a substantial part of their quota without policing or facing unforeseen obstacles" (letter of 17 October 1943, to Jacob Viner; Keynes, Collected Writings XXV, p. 333; emphasis added). To create this confidence, he needed three components: an international currency to supplement the limited supply of U.S. dollars and gold, generous limits on the amounts that countries could borrow, and automaticity in lending decisions. In all three domains, he faccd opposition from White and other U.S. officials, who were more concerned to avoid excessive credit creation.

First, an international currency. In Keynes's clearing union, central banks would pay subscriptions in gold and then would borrow in "bancor," an international currency that it could use only to settle debits against another central bank. Once created, bancor balances could not be redeemed on demand at the clearing union, but would be cancelled automatically when the borrowing country repaid its credits. Bancor thus was to be a form of "outside" money that would circulate in a closed economy limited to central banks. White's 1942 plan argued against introducing such an international currency, but it did accept that the International Bank - not the Stabilization Fund - should be given the power to issue notes against its gold reserves and that those notes should be denominated in an international unit of account (Horsefield, 1969, pp. 7882). His 1943 plan extended that concept to apply to the Fund as well, but eliminated its storeof-value function altogether. White's "unitas" was a sop to Keynes's concept, without any of its substance.

Second, a large Fund. After the initial plans were both on the table, Keynes suggested that total quotas of the Fund should be set at 75 percent of pre-war world trade (or around $\$ 38$ billion). The usable portion, however, would be less than half the total (i.e., countries would normally be able to borrow only $25-50$ percent of their quota). The more tight-fisted White suggested a Fund of "at least $\$ 5$ billion," all of which would, in principle, be available (countries could borrow up to 100 percent of quota). Once they settled on the larger allowance for drawings relative to quota, Keynes settled on a figure of $\$ 12$ billion as a reasonable target 
for a Fund that could combat the danger of deflation, or a bit more than double the size proposed by White. He also wanted the total to rise automatically each year in line with growth in world trade. Eventually, the U.S. delegation at Bretton Woods agreed to a compromise total of $\$ 8.8$ billion, to be reviewed only once every five years. ${ }^{20}$

Because the IMF was smaller than Keynes wanted and lacked an automatic mechanism for rising in line with the growth in world trade, it could not realistically fill the function of a lender of last resort, and the Fund would have to ration its scarce resources by imposing conditions on their use. The differences in magnitude might not seem all that significant to a $21^{\text {st }}$-century reader conditioned by news of $\$ 40$ billion rescue packages, but the implications emerge clearly from the updating shown in Table 1.

\begin{tabular}{|l|c|r|r|r|}
\hline \multicolumn{5}{|c|}{ Table 1. IMF Quotas, Access, and World Trade } \\
(in billions of U.S. dollars) \\
\hline & $\begin{array}{c}\text { Trade } \\
\text { (exports + imports) }\end{array}$ & Quotas & Access & $\begin{array}{c}\text { Access in Percent } \\
\text { of Trade }\end{array}$ \\
\hline 1942 (White) & 50 (pre-war base) & 5.0 & 5.0 & 10.0 \\
\hline 1943 (Keynes) & & 37.5 & 18.8 & 37.5 \\
\hline 1944 (Bretton Woods) & & 8.8 & 8.8 & 17.5 \\
\hline 1947 (ex-U.S.S.R.) & 100 & 7.5 & 7.5 & 7.5 \\
\hline 2000 (actual, rounded) & 12,000 & 300 & 900 & 7.5 \\
\hline 2000 equivalent of White & & 400 & 1,200 & 10.0 \\
\hline 2000 equivalent of Bretton Woods & & 700 & 2,100 & 17.5 \\
\hline 2000 equivalent of Keynes & & 1,500 & 4,500 & 37.5 \\
\hline
\end{tabular}

Current Fund quotas, adjusted for the higher current limits on access, have approximately the same relationship to world trade as quotas had in 1947, but that ratio was only about half what had been intended at Bretton Woods (owing to a doubling of world trade in terms of U.S. dollars between 1937-38 and 1947). To restore the relationship intended at Bretton Woods would require a bit more than a doubling of the existing quotas. To achieve the relationship desired by Keynes would require a quintupling of quotas. If Keynes was right about the requirements for a Fund that could create confidence in trade relations by serving as an international lender of last resort, then both White's Fund of 1944 and today's IMF fall well

${ }^{20}$ The aggregate of initial IMF quotas was reduced to $\$ 7.5$ billion because some countriesnotably the Soviet Union-decided not to join. Keynes's proposed magnitude (75 percent of pre-war trade) is in $\llbracket 6(5)$ of his 1943 plan; see Horsefield (1969), p. 23. White’s "at least $\$ 5$ billion" is from his 1942 plan; Horsefield, op. cit., p. 44. 
short. If White was right about the requirements for a lean Fund to discipline borrowers and avoid adding to inflationary pressures, then the IMF still reflects that vision.

As soon as the Fund began extending credits in 1947, White realized that he had been wrong in advocating such strict limits on the size of the Fund, because he had failed to anticipate the rapid postwar growth in the dollar value of world trade. To overcome what he now expected would be a widening shortage of Fund resources, he proposed to amend the Articles of Agreement "to provide an international medium of exchange to supplement the IMF resources for the purpose of making possible increases in international trade among the member countries" ("Proposal for Amendment ...," 1948, p. 4). Each member country would get a special temporary increase in its reserves in the form of "Trade Dollar Accounts," which it could spend anywhere "except probably in the United States and a few other countries" (Ibid.), but in the long run (after 15 years) it would have to return the reserves to the Fund. The excepted countries would be those that opted out of the plan voluntarily.

Unlike the 1967 amendments that introduced the SDR as an international reserve asset, White's proposal (which was not formally considered by the Fund's Executive Board) ${ }^{21}$ assumed that recipients would spend the allocations rather than holding them as reserves. Indeed, it encouraged them to do so, provided only that they would have to repay the allocations in the long run (when he assumed that the dollar shortage would have been eliminated). His specific scheme would almost certainly have been unworkable: How could the genie be put back in the bottle? Nonetheless, it does show that White was implicitly aware that Keynes had been more prescient than he, and that he was trying to correct the problem that had resulted. ${ }^{22}$

Third, an automatic lender. Keynes envisaged that his clearing union would extend credit virtually automatically on demand. Excessive credit creation would be avoided by restricting these credits to short-term, self-liquidating loans, for which "the analogy with a national banking system is complete." proceeds "to effect a balance in its economic relations with the rest of the world" and would be subjected to an increasing rate of interest and eventually to policy conditionality if it failed to repay the loan within the specified time limit. Keynes acknowledged that "disciplining a

${ }^{21}$ The paper was put in final form by the Fund staff after White's death and was circulated to the Board more as a tribute than as an active proposal. For White's original draft, see "Rough draft ...," 1948 .

${ }^{22}$ The SDR system was designed to avoid this problem by requiring participating countries to "reconstitute" their holdings within a specified time limit. Political pressures, however, led to the gradual relaxation and ultimate abrogation of this requirement (Boughton, 2001b, p. 933).

23 See1942 Keynes plan, 112 ; Horsefield (1969), p. 27. The implied reference was to the realbills doctrine, which at the time was the prevailing basis for central bank rediscounting and thus for national monetary control. 
misbehaving country" in this way would be difficult, but he argued that the task would be even

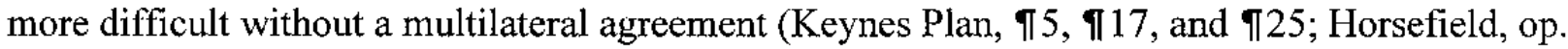
cit. pp. 6-9).

White designed his Stabilization Fund to prevent disequilibrium pressures, and he took a more symmetric view toward the dangers of instability (1942 White Plan; Horsefield, 1969, p. 47). Because excessive credit creation could be just as damaging as a shortage (especially for the United States, as the major creditor country), his plan envisaged giving the Fund discretion to reject requests for loans if the staff was not "satisfied proper steps were being taken to restore equilibrium" (Horsefield, op. cit., p. 52). ${ }^{24}$ In other words, policy conditionality was a more basic and up-front controlling device in White's plan than it was in Keynes's. Moreover, because his Fund would be relatively small, it would have to ration credits rather than making them freely available. In contrast to the Keynes Plan, the Stabilization Fund would not have the means to be an international lender of last resort. Rather than depending on the good behavior of borrowing countries, White was prepared to put his faith in the "technical knowledge, careful examination and good judgment by the Fund's staff" (Ibid.).

\section{Concluding Thoughts}

In trying to sort out intellectual from geopolitical influences on the design of the postwar international monetary system, the historian faces a problem of observational equivalence. Those applying the "realist" approach to international relations would stress the fact that White represented the country with much the greater economic power and that his positions on most key issues seem to have been dictated as much by U.S. economic and strategic interests as by his personal views. Those applying a more liberal-historical perspective would stress the broad consistency of White's intellectual development from his years in Harvard, through his efforts to promote financial stability and economic recovery in the $1930 \mathrm{~s}$, to his concern with developing a multilateral postwar system capable of avoiding the debacles that followed the first world war. Both approaches (see Waltz, 1979) help explain both White's view of international economic policy and his ability to have a dominant influence on the outcome. Both together are needed to reach a full understanding.

In the negotiations of 1943 and 1944 that led to the creation of the IMF, White's understanding and representation of U.S. economic interests were particularly important in shaping an international monetary system based on the dollar and its link to gold. Philosophically, nothing in White's writings suggests that he would have opposed creation of an international currency on principle, as long as it was linked - flexibly-to a golden anchor. If the choice had been between the pound and bancor, he surely would have chosen the latter.

24 "Symmetric" is used here only relative to the Keynes Plan. The White Plan and the final IMF agreement imposed stronger disciplinary measures on deficit than on surplus countries, but White did not intend to create a system in which creditor countries could accumulate surpluses without cost. His 1942 plan specifically aimed at engendering conditions under which the United States would gradually reduce its holdings of gold. 
Similarly, U.S. interests were paramount in White's insistence on limiting other countries' access to dollar credits. The United States would be providing most of the money in the Fund, and the only way Congress would approve the necessary legislation was to build in safeguards on how it would be used.

White's intellectual role came to the fore in two domains: his insistence on monetary stability as a disciplinary force and on multilateralism in international finance. Although White's belief in the importance of monetary stability dovetailed with the U.S. interest in having an institutional structure that would discipline debtor countries more than creditors, his convictions on this point were deeply rooted. His unilateral introduction of the "scarce currency" clause in the draft Articles of Agreement for the IMF, which was intended to limit the ability of the United States to accumulate credit balances against the rest of the world, is readily understood in this light. ${ }^{25}$ And White's personal convictions were even more important in the design of a multilateral institution that would help channel U.S. interests to meet global objectives. The Roosevelt administration faced powerful congressional opposition by isolationist and hegemonic interests. A bilateral hegemony shared with Britain, as envisaged by Keynes, might have served the narrow economic interests of the United States nearly as well as White's multilateral concept, but it would not have promoted global progress to the same degree.

${ }^{25}$ See Harrod (1951), pp. 543-48, and Skidelsky (2000), pp. 251-52. 


\section{REFERENCES}

\section{A. Archives}

IMF Central Files of the International Monetary Fund, Washington, DC.

NARA U.S. National Archives and Records Administration, College Park, Maryland.

WPP Harry Dexter White papers, Seeley G. Mudd Manuscript Library, Princeton University, Princeton, New Jersey.

\section{B. Documents}

(by Harry Dexter White, except as noted)

"Anglo-American Financial Agreement," address to the Civitan Club in Washington, DC (9 April 1946). WPP, Box 11.

"French Devaluation," U.S. Treasury memorandum from George C. Haas to Secretary Morgenthau, drafted by White (8 May 1936). NARA, RG56, Entry 360P, Box 1.

"The Future of Gold," draft manuscript dating from 1940-1944. WPP, Box 3.

"General Hines' suggestion that we revive the 'Buy American' slogan," memorandum to the Secretary (24 January 1938). NARA, RG56, Entry 360P, Box 2.

"Gold Imports into the United States," draft speech for Secretary Morgenthau (16 December 1935). WPP, Box 3.

"Increase in reserves against deposits in this country owned by residents of foreign countries," U.S. Treasury memorandum from George C. Haas to Secretary Morgenthau, drafted by White (11 January 1936). NARA, RG56, Entry 360P, Box 1.

"Managed Currency and the Gold Standard," U.S. Treasury memorandum from George C. Haas to Secretary Morgenthau, drafted by White (22 January 1935). NARA, RG56, Entry 360P, Box 1.

"Monetary Policy," note submitted to George C. Haas (13 November 1935). NARA, RG56, Entry 360P, Box 1 .

"Personal Report on London Trip," memorandum to George C. Haas (13 June 1935). WPP, Box 1. "Recovery Program: The International Monetary Aspect," memorandum to George C. Haas (15 March 1935). WPP, Box 2.

"Proposal for Amendment of Fund Agreement to Increase Level of World Trade," Executive Board Document No. 347 (October 14, 1948). IMF, S1140, "White Plan."

"Rough draft of a statement that might be used to introduce the proposed amendments on the agenda," (20 April 1948, signed on 19 May). WPP, Box 11.

"Selection of a Monetary Standard for the United States," report submitted to Jacob Viner, U.S. Treasury (22 September 1934). WPP, Box 1.

"Summary of Conversations," memorandum to George C. Haas (13 June 1935). WPP, Box 1. 
"The United Kingdom of Great Britain (Draft submitted to Mr. Haas October 18, 1935)"; NARA, RG56, Entry 360P, Box 1.

Untitled memorandum to Morgenthau, beginning "In our opinion ..." (31 March 1939); WPP, Box 6.

Untitled note, beginning "Should Germany succeed in defeating France and England ...," on the repercussions of a possible German victory (15 June 1940). WPP, Box 6 .

"What should our answer be to the British Treasury as to our attitude toward further depreciation of the franc?", memorandum to Secretary Morgenthau (30 April 1938). NARA RG 56, Entry 360P, Box 2.

\section{Publications}

Blum, John Morton, 1967. From the Morgenthau Diaries: Years of War, 1941-1945. Boston: Houghton Mifflin Co.

Boughton, James M., 2001a, "The Case Against Harry Dexter White: Still Not Proven," History of Political Economy, summer.

Boughton, James M., 2001b. Silent Revolution: The International Monetary Fund, 1979-1989. Washington: International Monetary Fund.

Boughton, James M., and Roger J. Sandilands, 2002, "Politics and the Attack on FDR's Economists: From the Grand Alliance to the Cold War," forthcoming in Intelligence and National Security.

Craig, Bruce, 1999. Treasonable Doubt: The Harry Dexter White Case, 1948-1953. Ph.D. Dissertation, Department of History, The American University. Ann Arbor, Michigan: UMI Dissertation Services.

Currie, Lauchlin, 1936, "Domestic Stability and the Mechanism of Trade Adjustments to International Capital Movements," in E. H. Phelps-Brown (editor), Explorations in Economics: Notes and Essays Contributed in Honor of F. W. Taussig, pp. 46-56. New York: McGraw-Hill.

Drummond, Ian, 1981. The Floating Pound and the Sterling Area, 1931-1939. Cambridge: Cambridge University Press.

Eckes, Alfred E., Jr., 1975, The Search for Solvency: Bretton Woods and the International Monetary System, 1941-1971. Austin: University of Texas Press.

Flanders, M. June, 1990. International Monetary Economics, 1870-1960. Cambridge, England: Cambridge University Press.

Flood, Robert P., and Peter Isard, 1989, "Monetary Policy Strategies" IMF Staff Papers, Vol. 36, No. 3 (September), pp. 612-32.

Gardner, Richard N. 1980, Sterling-Dollar Diplomacy in Current Perspective: The Origins and the Prospects of Our International Economic Order. New York: Columbia University Press. 
Harrod, Roy, 1951. The Life of John Maynard Keynes. London: Macmillan \& Co.

Horsefield, J. Keith, 1969. The International Monetary Fund, 1945-1965. Vol. 3, Documents. Washington: International Monetary Fund.

Keynes, John Maynard, various dates. The Collected Writings of John Maynard Keynes. Volume IX, Essays in Persuasion. Vol. XXI, Activities 1931-1939, World Crises and Policies in Britain and America, edited by Donald Moggridge. Vol. XXV, Activities 1940-1944, Shaping the Post-War World: The Clearing Union, edited by Donald Moggridge. Vol. XXV1, Activities 1941-1946, Shaping the Post-War World: Bretton Woods and Reparations, edited by Donald Moggridge. London, Macmillan \& Co.

Kindleberger, Charles P., 1991. The Life of an Economist: An Autobiography. Oxford: Blackwell.

Laidler, David E. W., 1999. Fabricating the Keynesian Revolution: Studies of the Inter-War Literature on Money, the Cycle, and Unemployment.

Laidler, David E. W., 2001, "Rules, Discretion and Financial Crises in Classical and Neoclassical Monetary Economics," manuscript (May).

Laidler, David E. W., and Roger J. Sandilands, 2002, "An Early Harvard Memorandum on Anti-Depression Policies: Introductory Note," History of Political Economy, summer (forthcoming). [Research Report 2000-4, Department of Economics, University of Western Ontario, Canada.]

Lekachman, Robert, 1967. The Age of Keynes. London: Allen Lane, The Penguin Press.

Moggridge, Donald E., 1992. Maynard Keynes: An Economist's Biography. London and New York: Routledge.

Pressnell, L. S., 1986. External Economic Policy Since the War. Volume I: The Post-War Financial Settlement. London: Her Majesty's Stationery Office.

Rees, David, 1973. Harry Dexter White: A Study in Paradox. New York: Coward, McCann \& Geoghagan.

Sandilands, Roger J., 1990. The Life and Political Economy of Lauchlin Currie: New Dealer, Presidential Adviser, and Development Economist. Durham, N.C.: Duke University Press.

Skidelsky, Robert, 1992. John Maynard Keynes: The Economist as Saviour. London: MacMillan. , 2000. John Maynard Keynes: Fighting for Britain, 1937-1946. London: MacMillan.

Stein, Herbert, 1969. The Fiscal Revolution in America. Chicago: The University of Chicago Press. 
Taussig, Frank W., 1931. Some Aspects of the Tariff Question: An Examination of the Development of American Industries under Protection. Third Enlarged Edition, Continued to 1930, with the Cooperation of H. D. White. Cambridge, Mass.: Harvard University Press.

Waltz, Kenneth N., 1979. Theory of International Politics. Reading, Mass.

White, Harry Dexter, 1933. The French International Accounts, 1880-1913. Cambridge, Mass.: Harvard University Press.

, 1934, "Haberler's Der Internationale Handel and Ohlin's Interregional and International Trade," Quarterly Journal of Economics, Vol. 48 (August), pp. 727-41. , 1943, "Postwar Currency Stabilization," American Economic Review (Papers and Proceedings), Vol. 33 (March), pp. 382-87. , 1945, "The Monetary Fund: Some Criticisms Examined," Foreign Affairs, Vol. 23 (January), pp. 195-210.

, 1947, "The International Monetary Fund: The First Year," Annals of the American Academy of Political and Social Science, Vol. 252 (July), pp. 21-29.

Young, Allyn, 1929, "Downward Price Trend Probable, Due to Hoarding of Gold by Central Banks," The Annalist, Vol. 33 (January 18), pp. 96-97. Reprinted in Perry G. Mehrling and Roger J. Sandilands (Editors), 1999, Money and Growth: Selected Papers of Allyn Abbott Young. London and New York: Routledge. 